\title{
IDENTIFIKASI SISTEM PANAS BUMI DAERAH WAPSALIT BERDASARKAN STRUKTUR TAHANAN JENIS DATA MAGNETOTELLURIK
}

\section{IDENTIFICATION OF GEOTHERMAL SYSTEM IN WAPSALIT AREA BASED ON MAGNETOTELLURIC RESISTIVITY STRUCTURE}

\author{
Iqbal Takodama, Ahmad Zarkasyi, Mochammad Nur Hadi, dan Ratna Dewi \\ Pusat Sumber Daya Mineral Batubara dan Panas Bumi \\ iqbal.takodama@esdm.go.id
}

\begin{abstract}
ABSTRAK
Daerah panas bumi Wapsalit berada di Pulau Buru, Maluku, Indonesia yang secara geologi berada pada lingkungan non-vulkanik. Berdasarkan penyelidikan terdahulu, daerah ini memiliki prospek panas bumi di sekitar area manifestasi panas bumi yang dikontrol oleh perpotongan dua sesar. Proses inversi 2-Dimensi dari data magnetotellurik (MT) dilakukan untuk menggambarkan sebaran tahanan jenis batuan bawah permukaan. Proses inversi ini menggunakan algoritma Active Constraint Balancing (ACB) yang memanfaatkan prinsip spatially variable regularization parameter. Lapisan konduktif yang berfungsi sebagai lapisan penudung berupa batuan metamorf terubah muncul di dekat permukaan hingga kedalaman 1000 - 1250 meter. Lapisan ini semakin meninggi seiring dengan kedalaman yang mengindikasikan zona reservoir. Zona tahanan jenis tinggi (resistif) dengan bentuk kubah muncul pada bagian bawah yang diinterpretasikan sebagai batuan intrusif muda.
\end{abstract}

Kata kunci: Wapsalit, metode magnetotellurik, inversi 2-D, Active Constraint Balancing, tahanan jenis, sistem panas bumi

\section{ABSTRACT}

Wapsalit geothermal area is non-volcanic geothermal system and located in Buru Island, Maluku, Indonesia. Based on previous investigations, the promising zone is located around surface manifestation which is controlled by an intersection of two faults. The 2-D inversion of magnetotelluric (MT) data has been carried out to image the 2-D model of electrical resistivity distribution. Active Constraint Balancing (ACB) algorithm was used in inversion process by using the spatially variable regularization parameter. Altered metamorphic rock acted as cap rock of the geothermal system is shown in resistivity model by conductive layer on the top layer from near surface until 1,000 - 1,250 $\mathrm{m}$ depth. This conductive layer is followed by medium to high resistivity zone, which may indicate the reservoir zone. High resistivity zone with dome shape is located at the bottom layer which is interpreted as young intrusive volcanic rock.

Keywords: Wapsalit, magnetotelluric method, 2-D inversion, Active Constraint Balancing, resistivity, geothermal system

\section{PENDAHULUAN}

Indonesia merupakan salah satu negara yang dilewati oleh cincin api (Ring of Fire), dan mempunyai lebih dari 120 gunungapi aktif. Keberadaan gunungapi aktif ini tidak hanya memberikan bencana, namun juga memberikan keuntungan berupa pemanfaatan sumber daya alamnya. Panas bumi merupakan salah satu keuntungan dari keberadaan gunungapi. Namun demikian, gunungapi bukan merupakan satu-satunya sumber dari panas bumi, tetapi juga dari hot dry rock dan hot sedimentary aquifer (Goldstein dkk., 2009) (King \& Miller, 2010). 


\section{MAKALAH ILMIAH}

Dengan sejumlah 342 lokasi panas bumi dan masih terus bertambah dengan penelitian lebih lanjut, Indonesia mempunyai potensi panas bumi yang sangat besar, walaupun belum sepenuhnya dimanfaatkan. Oleh karena itu, untuk memaksimalkan potensi panas bumi, penelitian harus dilakukan dari permukaan hingga bawah permukaan. Eksplorasi geofisika menggunakan metode magnetotellurik (MT) merupakan salah satu metode yang sangat efektif untuk mendapatkan informasi distribusi tahanan jenis bawah permukaan. Informasi tahanan jenis bawah permukaan ini dapat mengidentifikasi sistem panas bumi seperti reservoir, caprock, dan juga struktur yang berkembang. Studi kasus mengenai metode MT yang digunakan: untuk eksplorasi panas bumi telah banyak dilakukan (Uchida dkk., 2011), (Buonasorte dkk., 2013), (Kholid dkk., 2015), (Niasari dkk., 2015) and (Zarkasyi \& Takodama, 2016).

Daerah panas bumi Wapsalit terletak di Pulau Buru, Provinsi Maluku (Gambar 1), Indonesia bagian timur, yang mempunyai banyak manifestasi panas bumi berupa fumarol, tanah panas dan mataair panas dengan temperatur $100^{\circ} \mathrm{C}$ (Hadi dan
Sulaeman, 2010). Sistem panas bumi Wapsalit berupa sistem panas bumi nonvulkanik dengan area prospek yang terletak di sekitar manifestasi permukaan. Tubuh batuan intrusi/vulkanik di bawah manifestasi permukaan yang tidak tersingkap di permukaan diperkirakan sebagai sumber panas yang memanaskan fluida reservoir. Keberadaan tubuh batuan intrusi di bawah zona prospek ditunjukkan oleh adanya anomali tinggi dari data gaya berat (Rezky and Zarkasyi, 2010).

Tujuan utama dari penelitian ini adalah untuk mengidentifikasi sistem panas bumi daerah Wapsalit berdasarkan distribusi tahanan jenis. Tahanan jenis merupakan salah satu sifat fisis batuan yang dapat digunakan dalam mendeliniasi zona prospek panas bumi.

Makalah ini menyajikan langkah-langkah pengolahan, pemodelan, dan analisis data MT untuk eksplorasi panas bumi di daerah Wapsalit. Pada penelitian ini, algoritma Active Constraint Balancing (ACB) digunakan dalam proses inversi 2-D dari data MT dan program opensource MT2DInvMatlab digunakan dalam melakukan proses inversi 2-D (Lee dkk., 2009).

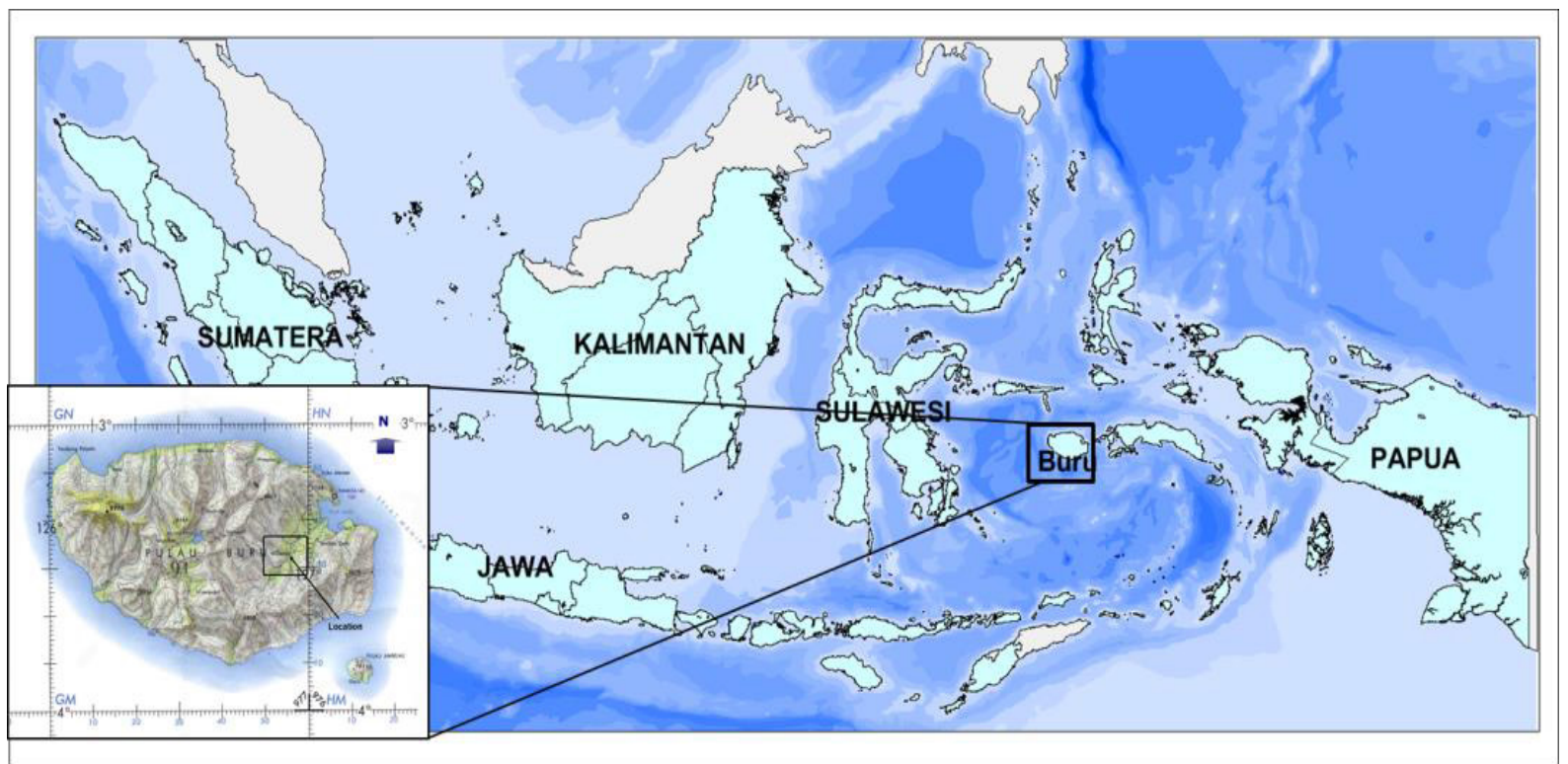

Gambar 1. Lokasi daerah panas bumi Wapsalit 


\section{TATAAN GEOLOGI}

Pulau Buru terletak di bagian barat dari Kepulauan Maluku (Gambar 1). Pulau Buru terbentuk dari fasies non-vulkanik PraTersier pada busur luar Tanimbar-KaiSeram. Sesar mendatar Sorong yang berasosiasi aktif dengan pergerakan lempeng Indo-Australia ke arah utara mempengaruhi tataan geologi di Pulau Buru. Daerah Wapsalit terletak di tengah dari bagian selatan Pulau Buru dan terbentuk dari proses pengendapan dan metamorfisma di daerah topografi sedang (Hadi \& Sulaeman, 2010)

Susunan litologi daerah Wapsalit dari yang termuda hingga tertua terdiri atas: batuan metamorf, batuan sedimen, teras aluvial dan aluvium, seperti yang ditunjukkan pada Gambar 2. Batuan metamorf PraTersier dikelompokkan sebagai batuan dengan derajat ubahan rendah, seperti: batusabak, filit, dan kuarsit. Sekis hijau dan arkos ditemukan di bagian barat dari manifestasi permukaan. Batuan sedimen berumur Pleistosen ditemukan bersama batulempung dan batupasir kasar sebagai ketidakselarasan dengan arah jurus dan kemiringan sekitar $\mathrm{N} 275^{\circ} \mathrm{E} / 15^{\circ}$ $\mathrm{N} 310^{\circ} \mathrm{E} / 10^{\circ}$. Ketebalan batulempung berkisar antara 20 hingga $150 \mathrm{~cm}$ dan batupasir berkisar antara $30-50 \mathrm{~cm}$. Teras alluvial berumur Pleistosen didominasi oleh hancuran batuan konglomerat yang fragmennya terdiri atas batuan metamorf seperti filit, sekis, batusabak, kuarsit, pasir, dan lempung. Aluvium juga muncul di sekitar dataran sungai Wae Apo.

Struktur geologi yang berkembang di daerah ini berupa sesar yang muncul di daerah panas bumi Wapsalit. Sesar
Wapsalit berarah barat daya - timur laut terletak di bagian tengah daerah penelitian. Di bagian selatan terdapat sesar mendatar menganan Waetina yang berarah barat daya - timur laut dan beberapa sesar kecil dengan arah yang sama di area ini. Sesar Waekedang berarah barat laut - tenggara yang membentuk Sungai Pemali juga muncul di area ini. Sesar ini diduga sebagai pengontrol kemunculan manifestasi panas bumi ke permukaan. Sesar normal Debu berarah barat laut - tenggara muncul di sebelah timur sesar Waekedang. Sesar Waemetar muncul di antara sesar Waekedang dan Debu dengan arah yang sama.

Manifestasi panas bumi di daerah Wapsalit muncul sebagai mata air panas, tanah panas, steam vent, endapan (deposit) belerang dan garam, serta batuan alterasi (Hadi dan Sulaeman, 2010). Sebagian besar manifestasi permukaan berada di sekitar Sungai Wapsalit/Pemali dan Waemetar (Gambar 3). Mata air panas Wapsalit 1 sampai dengan 3 mempunyai temperatur yang berkisar dari $98^{\circ} \mathrm{C}$ hingga $102^{\circ} \mathrm{C}$ dengan $\mathrm{pH}$ asam, kecuali pada mata air panas Wapsalit 3 yang mempunyai $\mathrm{pH}$ netral. Berjarak dua kilometer ke arah timur, terdapat mataair panas Metar yang terletak di Sungai Waemetar dengan temperatur $63^{\circ} \mathrm{C}$ hingga $98^{\circ} \mathrm{C}$ dan $\mathrm{pH}$ netral. Tanah panas dengan temperatur $850 \mathrm{C}$ hingga $98^{\circ} \mathrm{C}$, gas belerang, silika sinter dan batuan ubahan muncul di sekitar Sungai Pemali. Perkiraan temperatur bawah permukaan dengan menggunakan geothermometer $\mathrm{SiO} 2$ (conductive-cooling) rata-rata berkisar antara $224-247^{\circ} \mathrm{C}$ dan termasuk kedalam entalpi tinggi (Hadi \& Sulaeman, 2010). 


\section{MAKALAH ILMIAH}

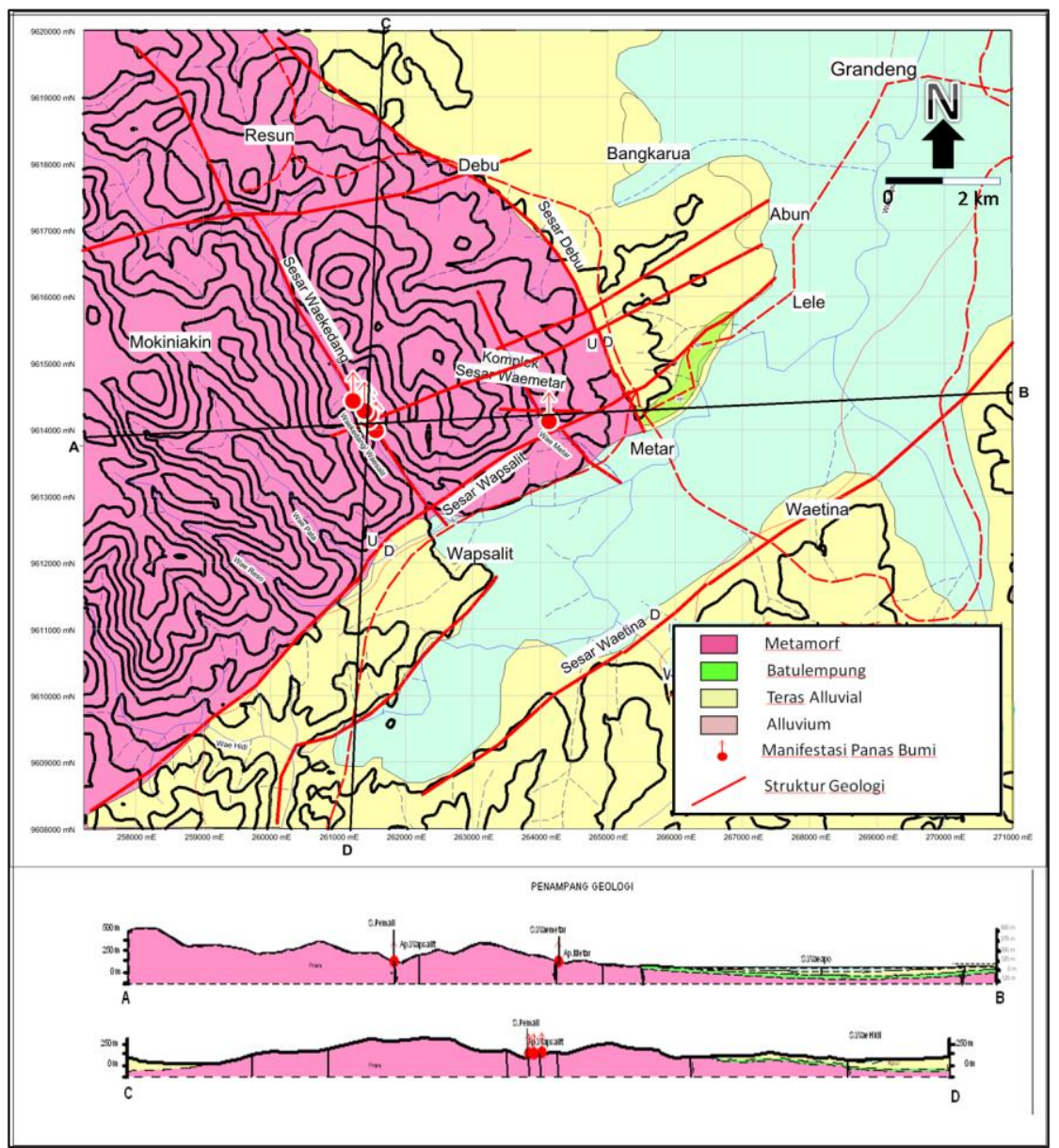

Gambar 2. Peta geologi daerah panas bumi Wapsalit

(dimodifikasi dari Hadi \& Sulaeman, 2010)

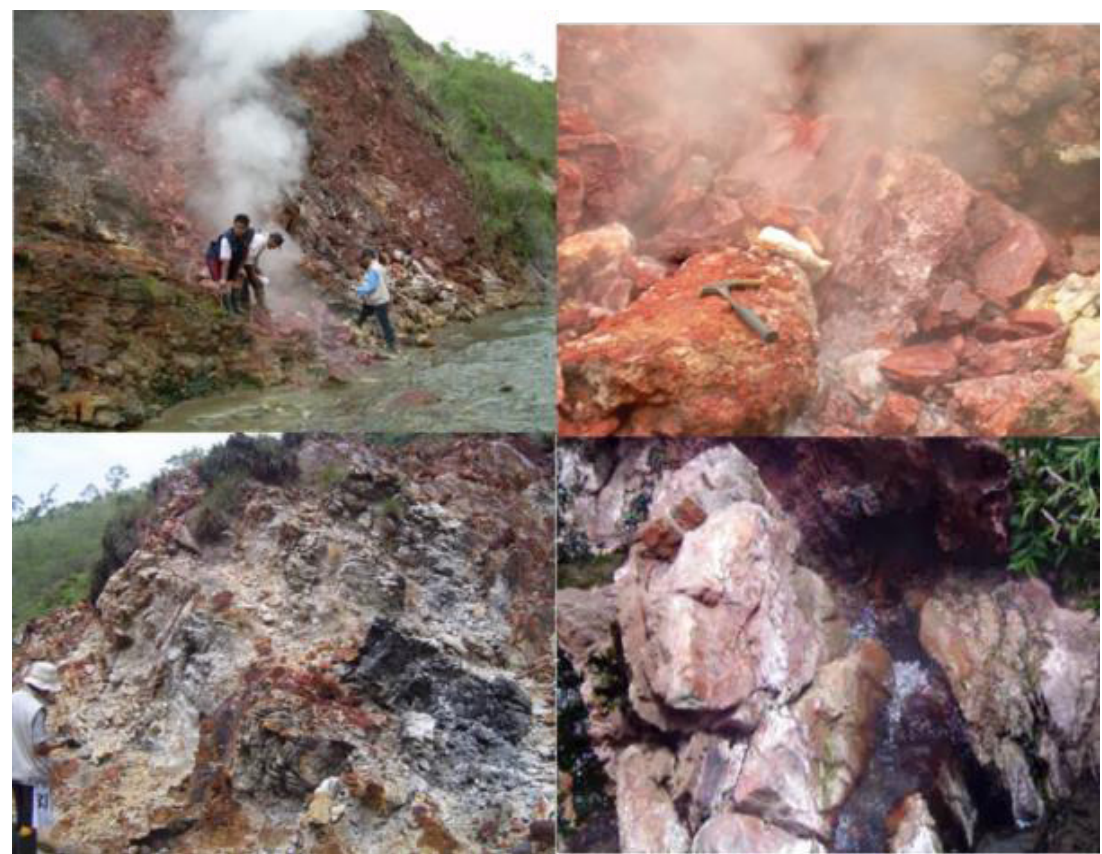

Gambar 3. Manifestasi panas bumi daerah panas bumi Wapsalit

(Sesuai arah jarum jam dari foto kiri atas; mataair panas Wapsalit 1, mataair panas Wapsalit 2, mataair panas Wapsalit 3 dan batuan alterasi) (Hadi \& Sulaeman, 2010) 
Batuan ubahan, teramati di sekitar manifestasi permukaan dengan berbagai warna, dari putih hingga hitam kecoklatan. Perbedaan warna ini menunjukkan tingginya intensitas kontak batuan induk dengan fluida hidrotermal. Mineral alterasi yang ditemukan menunjukan tipe alterasi argilik hingga argilik lanjut. Tipe argilik ditunjukkan dengan keberadaan haloysit, dickit dan kaolin, sedangkan tipe argilik lanjut ditunjukkan dengan kaolin, dickit, alunit, opal dan mika seperti muskovit (Hadi dan Sulaeman, 2010).

Proses pembentukan sistem panas bumi Wapsalit berbeda dengan sistem panas bumi lainnya yang berasosiasi dengan aktivitas vulkanik. Sistem panas bumi Wapsalit berasosiasi dengan tubuh intrusi/vulkanik yang tidak tersingkap ke permukaan. Fluida bawah permukaan bergerak ke atas melalui rekahan-rekahan yang terbentuk dari aktivitas tektonik. Fluida ini dipanaskan oleh tubuh intrusi yang berlaku sebagai sumber panas di sistem panas bumi Wapsalit.

\section{METODE MAGNETOTELLURIK TEORI DASAR}

Metode MT merupakan salah satu metode geofisika yang dapat menggambarkan sifat elektrik (distribusi tahanan jenis) bawah permukaan yang memanfaatkan variasi medan elektromagnetik alami sebagai sumbernya. Rentang frekuensi dari medan elektromagnet alami berkisar antara $10^{-4} \mathrm{~Hz}$ hingga $10^{4} \mathrm{~Hz}$ (Chave \& Jones, 2012). Frekuensi tinggi, lebih dari 1 $\mathrm{Hz}$, dihasilkan dari aktivitas petir, sedangkan untuk frekuensi rendah, kurang dari $1 \mathrm{~Hz}$ dihasilkan dari interaksi solar wind dan medan magnet bumi.

Dari persamaan Maxwell, medan listrik $(E)$ dan medan magnet $(H)$ tegak lurus terhadap satu sama lain. Perbandingan antara medan magnet dan listrik menghasilkan impedansi $(Z)$ yang berkorelasi dengan tahanan jenis listrik $(\rho)$ bumi (Chave \& Weidelt, 2012)

$$
Z=\frac{E_{x}}{H_{y}}=-\frac{E_{y}}{H_{x}}
$$

Di mana $x$ dan y masing-masing berarah utara dan timur.

Penurunan dari persamaan Maxwell ini kemudian akan menghasilkan nilai tahanan jenis semu $\left(\rho_{a}\right)$ dan fase $(\varphi(\omega))$ yang tergantung pada frekuensi (Chave \& Weidelt, 2012).

$$
\begin{gathered}
\rho_{a}(\omega)=\frac{|Z|^{2}}{\omega \mu_{0}}, \\
\varphi(\omega)=\tan ^{-1} \frac{\operatorname{Im}[Z]}{\operatorname{Re}[Z]},
\end{gathered}
$$

Di mana $\rho_{a}(\omega)$ adalah tahanan jenis semu $(\Omega \mathrm{m}), \varphi(\omega)$ adalah sudut fase, dengan $\omega=$ $2 \pi f$, dan $\mu_{0}$ adalah permeabilitas magnet.

\section{Model bumi 2-Dimensi}

Dalam kasus model bumi 2-D, tensor impedansi $Z$ dapat ditulis sebagai:

$$
\left[\begin{array}{l}
E_{x} \\
E_{y}
\end{array}\right]=\left[\begin{array}{cc}
0 & Z_{x y} \\
Z_{y x} & 0
\end{array}\right]\left[\begin{array}{l}
H_{x} \\
H_{y}
\end{array}\right]
$$

Dalam kasus ini, komponen $Z_{x y}$ tidak sama dengan $Z_{y x}$. Medan elektromagnet total dapat dipisahkan menjadi dua modus yang independen, yaitu modus transvere electric (TE) dan transverse magnetic (TM). Pada modus TE, arus telurik merambat sepanjang struktur sedangkan pada modus TM, arus tellurik mengalir tegak lurus struktur (Chave \& Weidelt, 2012).

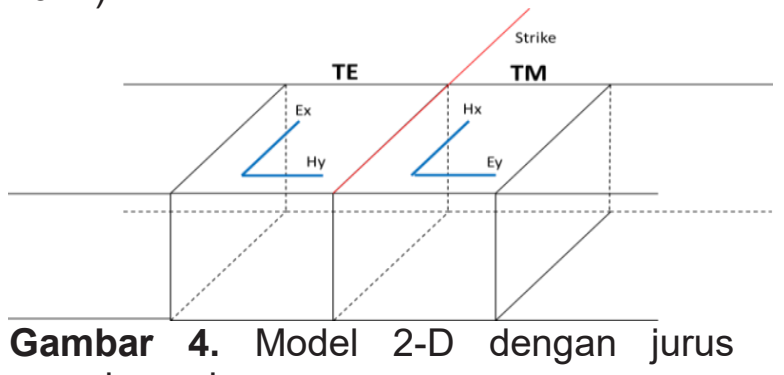
searah sumbu $\mathrm{X}$. 
Jika arah jurus serah dengan sumbu-x seperti yang ditunjukkan oleh Gambar 4, maka $E_{x}$ searah dengan arah jurus untuk $Z_{T E}$ (modus TE), sedangkan $E_{y}$ tegak lurus dengan arah jurus untuk $Z_{T M}$ (modus TM).

\section{Inversi}

Proses pemodelan inversi data MT diperlukan dalam rangka menggambarkan distribusi nilai tahanan jenis bawah permukaan. Pemodelan inversi ini sering pula disebut sebagai data fitting karena dalam prosesnya dicari parameter model yang menghasilkan respons yang fit dengan data pengamatan. Model yang dihasilkan dari proses pemodelan inversi bersifat tidak unik. Ketidak-unikan (nonuniqueness) solusi pemodelan geofisika adalah akibat dari paling tidak tiga hal utama, yaitu: sifat fisika fenomena yang ditinjau, adanya kesalahan atau bising (noise) pada data dan kekurangan data dalam membatasi atau mendefiniskan (menjadi constrain) solusi (Grandis, 2009).

Dalam MT2DInvMatlab, smoothnessconstrained least-squares inversion diadopsi untuk menyelesaikan masalah regularisasi inversi (Lee dkk., 2009). Linearisasi dari persamaan dalam forward modeling dan beberapa manipulasi menghasilkan persamaan:

$$
\Delta \boldsymbol{m}=\left(\boldsymbol{J}^{T} \boldsymbol{J}+\lambda^{2} \boldsymbol{C}^{T} \boldsymbol{C}\right)^{-1} \boldsymbol{J}^{T} \Delta \boldsymbol{d},
$$

Di mana $\Delta \boldsymbol{d}$ merupakan vektor error antara data hasil kalkulasi dengan observasi, $\Delta \mathbf{m}$ merupakan perubahan model yang didapatkan, $\boldsymbol{J}$ merupakan matriks Jacobian atau matriks sensitivitas pada forward modeling pada operator $A, C$ merupakan operator kehalusan Laplacian (orde kedua), dan $\lambda$ merupakan parameter regularisasi (Lagrange multiplier) atau trade-off antara model constraint dan data misfit (Lee dkk,, 2009).

Penentuan parameter regularisasi dapat menjadi hal yang kritis dalam mendapatkan resolusi dan stabilitas. Lagrange multiplier yang besar akan membuat konstrain atau regularisasi yang lebih besar, namun resolusi yang buruk.
Sebaliknya, Lagrange multiplier yang kecil akan membuat solusi menjadi tidak stabil. Algoritma Active Constraint Balancing (ACB) menggunakan Lagrange multiplier yang diatur secara optimal oleh spread function SPi pada parameter model ke-i. Nilai $\lambda$ bervariasi berdasarkan resolusi dari setiap blok inversi. Matriks resolusi parameter $R$ dapat didapatkan pada proses inversi dengan mengalikan pseudo-inverse $\boldsymbol{J}^{-9}$ dengan matriks Jacobian $\boldsymbol{J}$ (Lee dkk., 2009).

$$
\begin{gathered}
\boldsymbol{R}=\boldsymbol{J}^{-g} \boldsymbol{J}, \\
\boldsymbol{J}^{-g}=\left(\boldsymbol{J}^{T} \boldsymbol{J}+\lambda^{2} \boldsymbol{C}^{T} \boldsymbol{C}\right)^{-1} \boldsymbol{J}^{T} .
\end{gathered}
$$

Spread function $S P_{i}$ pada parameter model ke-I dapat dituliskan dengan:

$$
S P_{i}=\sum_{j=1}^{M}\left\{w_{i j}\left(1-S_{i j}\right) R_{i j}\right\}^{2},
$$

Di mana $\mathrm{M}$ merupakan jumlah iterasi, $w_{\mathrm{ij}}$ adalah faktor pembobotan dari matriks resolusi $\mathrm{R}$, dan $S_{i j}$ merupakan matriks yang digabungkan pada regularisasi (Yi dkk., 2003). Parameter regularisasi $\lambda(x, y)$ diatur dalam interpretasi log-linear diatur dalam:

$$
\begin{gathered}
\log \left(\lambda_{i}\right)=\log \left(\lambda_{\text {min }}\right)+ \\
\frac{\log \left(\lambda_{\max }\right)-\log \left(\lambda_{\min }\right)}{\log \left(S P_{\max }\right)-\log \left(S P_{\min }\right)} \times\left\{\log \left(S P_{i}\right)-\right. \\
\left.\log \left(S P_{\min }\right)\right\} .
\end{gathered}
$$

Nilai parameter regularisasi pada model model ke-i dengan $\lambda_{\min }$ dan $\lambda_{\max }$ diatur melalui kondisi yang ditentukan sebelumnya.

MT2DInvMatlab menghitung nilai rata-rata tahanan jenis semu secara otomatis dan menggunakannya sebagai nilai awal dari inversi pada tiap model. Blok inversi vertikal didapatkan dengan mengatur tiga parameter, yaitu: Max Domain Factor, Block Inc Factor, dan Surface-Block Thickness. Ketebalan lapisan paling atas didefinisikan sebagai Surface-Block Thickness dan kemudian akan bertambah sesuai dengan nilai Blocklnc Factor, 
hingga mencapai skin depth maksimum dikalikan dengan Max Domain Factor. Nilai maksimum dan minimum dari skin depth diestimasi dari frekuensi maksimum dan minimum, serta nilai rata-rata logaritmik dari nilai tahanan jenis semunya. Secara horizontal, satu blok dapat disisipkan di antara dua titik MT dan sebuah titik MT diletakkan di tengah blok. Ukuran blok horizontal tergantung pada jarak antar titik MT (Lee dkk., 2009).

Setelah beberapa proses percobaan inversi untuk semua lintasan dengan menggunakan parameter yang berbedabeda, didapatkan parameter inversi yang sesuai dengan kondisi geologi daerah Wapsalit yang ditunjukkan dalam tabel 1 . Dalam tabel tersebut, ditampilkan juga misfit error dan model constraint error yang dihasilkan dalam proses inversi. Model awal dari setiap lintasan bervariasi tergantung dari nilai rata-rata logaritmik tahanan jenis semu dari setiap lintasan. Rentang frekuensi yang digunakan berkisar dari 0,01 hingga $320 \mathrm{~Hz}$, rentang nilai parameter regularisasi diatur dari 4 hingga 10. Nilai Max Domain Factor, Block Inc Factor, dan Surface-BlockThickness, masing-masing bernilai 0,05; 1,2 dan 30, digunakan untuk semua lintasan. Untuk memenuhi tujuan dari penelitian ini, kedalaman untuk setiap lintasan hanya ditampilkan sampai dengan kedalaman $3.500 \mathrm{~m}$.

\section{HASIL}

Pengukuran MT di daerah Wapsalit mencakup 58 titik yang terbagi dalam delapan lintasan berarah barat daya timur laut (lintasan $\mathrm{A}-\mathrm{H}$ ) seperti pada Gambar 5. Jarak antar titik pengukuran berkisar antara $500-1.000 \mathrm{~m}$. Arah lintasan pengukuran dibuat tegak lurus dengan arah struktur geologi utama yang berarah barat laut - tenggara. Manifestasi permukaan terletak di sekitar lintasan D dan $\mathrm{E}$ dan dikontrol oleh perpotongan dua struktur geologi.

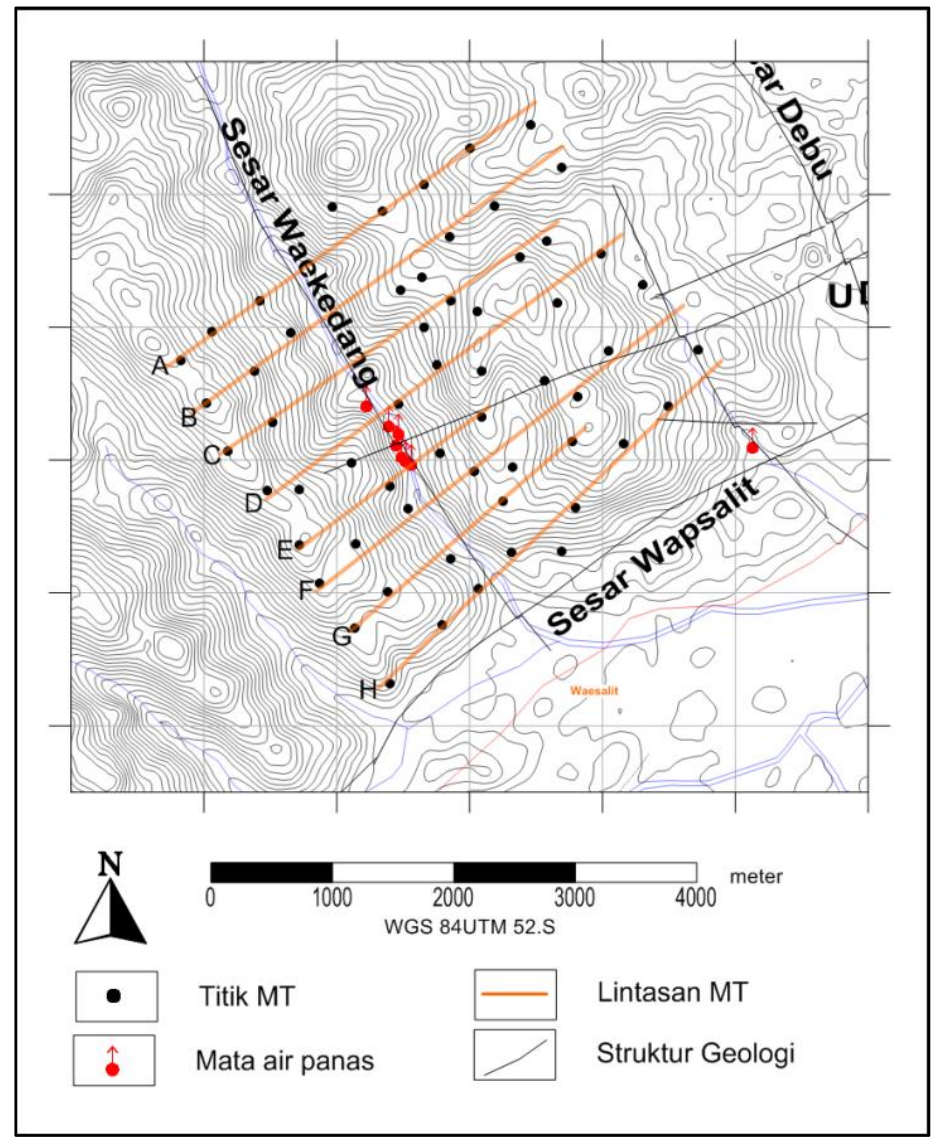

Gambar 5. Distribusi titik ukur MT di daerah panas bumi Wapsalit 


\section{MAKALAH ILMIAH}

Dari Gambar 5, manifestasi permukaan (mata air panas, fumarol, tanah panas dan zona alterasi) terletak di tengah lintasan D dan E. Daerah ini diperkirakan sebagai zona prospek dari daerah panas bumi Wapsalit berdasarkan penelitian sebelumnya (Zarkasyi \& Takodama, 2016). Gambar 6 menunjukkan pseudosection dari data hasil pengukuran dan model dari lintasan D untuk inversi TE dan TM. Kurva sounding dari data MT-09, MT-
21A, MT-88 dan MT-90 ditunjukkan pada gambar 7. Secara umum, model tahanan jenis semu dan fase untuk setiap modus TE dan TM cukup bersesuaian dengan data pengukuran. Namun, modus TM lebih sesuai responnya dari pada modus TE. Hal ini dikarenakan adanya ketidakseragaman dekat permukaan dan efek topografi.

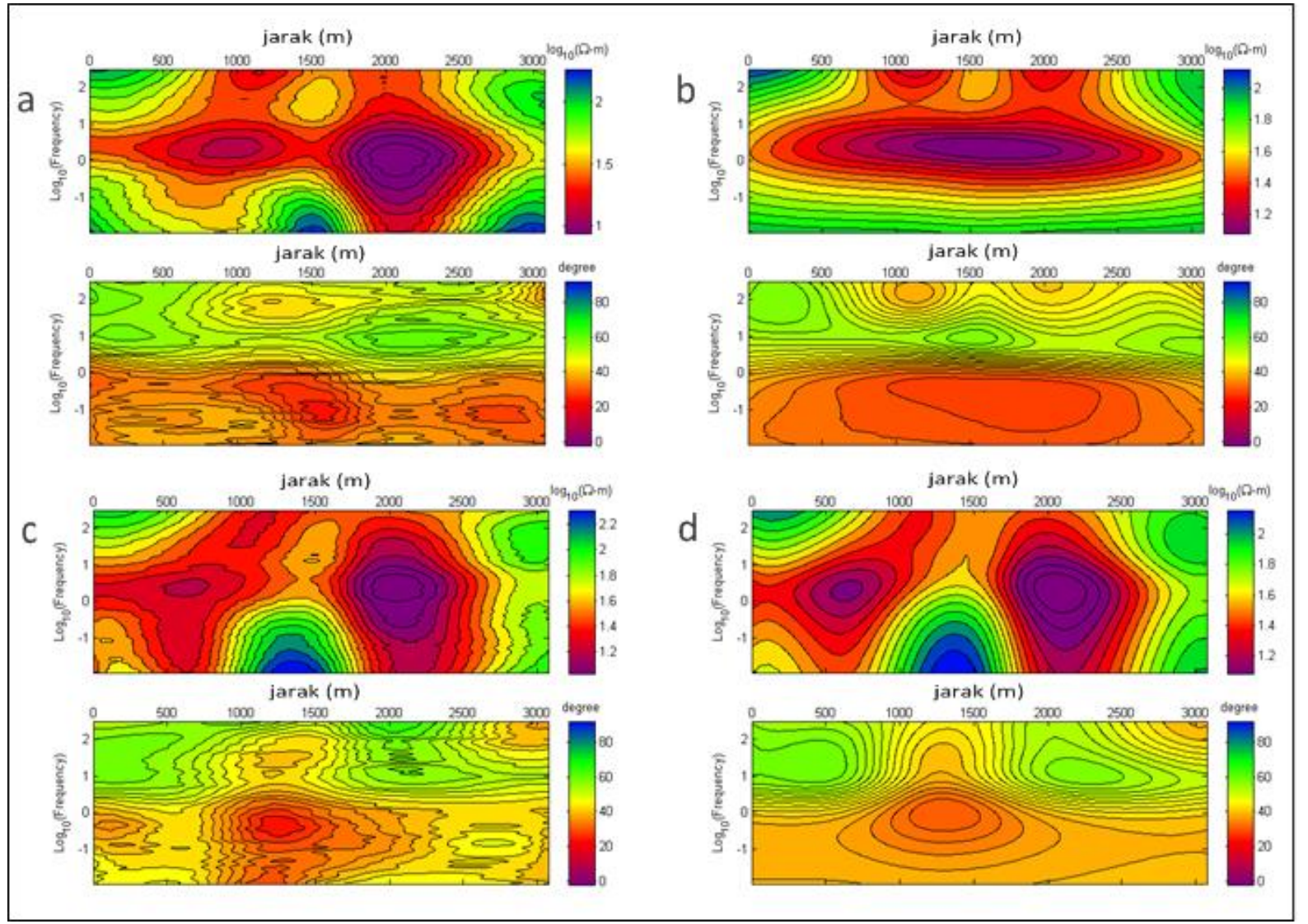

Gambar 6. Perbandingan data observasi dengan respon model pada modus TE (a dan $b$ ) dan TM (c dan d) pada inversi gabungan modus TE dan TM pada lintasan D.

Gambar atas menunjukkan tahanan jenis semu dan gambar bawah menunjukkan fase. 


\section{MAKALAH ILMIAH}

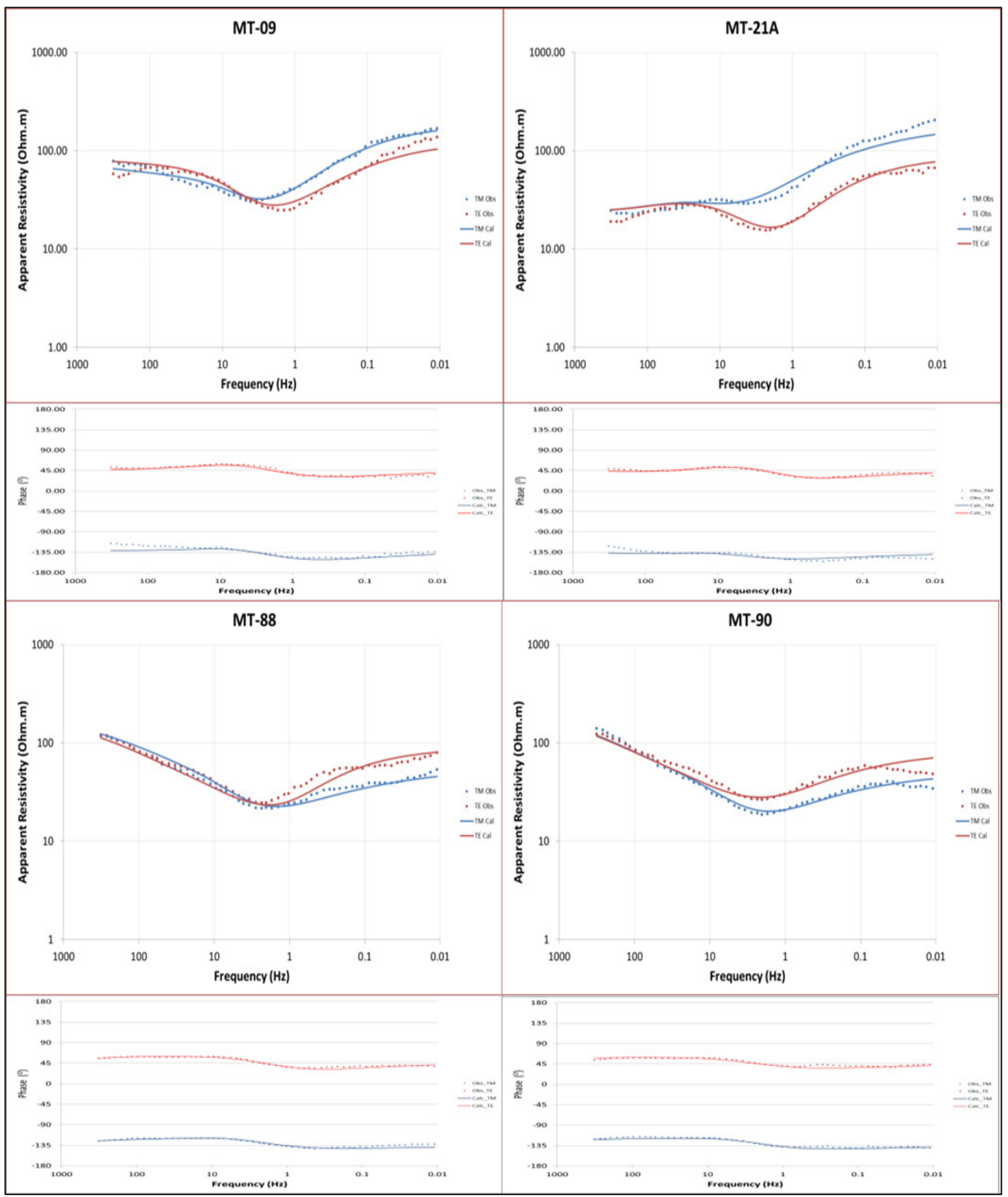

Gambar 7. Kurva misfit pada sebagian data MT pada modus TE dan TM.

Garis putus-putus berwarna merah dan biru menggambarkan data observasi modus TE dan TM, sedangkan garis penuh berwarna merah dan biru menunjukkan respon model dari modus TE dan TM. 


\section{MAKALAH ILMIAH}

Tabel 1. Parameter inversi pada semua lintasan

\begin{tabular}{lccccc}
\hline Lintasan & Iterasi & $\begin{array}{c}\text { Model Awal } \\
(\mathbf{\Omega m})\end{array}$ & $\begin{array}{c}\text { Jumlah } \\
\text { Blok }\end{array}$ & $\begin{array}{c}\text { Misfit } \\
\text { error }\end{array}$ & $\begin{array}{c}\text { Model } \\
\text { constraint error }\end{array}$ \\
\hline Lintasan-A & 5 & 75,94 & 342 & 0,2078 & 0,0163 \\
\hline Lintasan-B & 5 & 58,14 & 304 & 0,1550 & 0,0111 \\
\hline Lintasan-C & 5 & 50,62 & 225 & 0,1212 & 0,0091 \\
\hline Lintasan-D & 5 & 40,58 & 361 & 0,2066 & 0,0160 \\
\hline Lintasan-E & 5 & 30,80 & 154 & 0,1810 & 0,0141 \\
\hline Lintasan-F & 5 & 45,79 & 289 & 0,1971 & 0,0164 \\
\hline Lintasan-G & 5 & 61,75 & 255 & 0,1976 & 0,0215 \\
\hline Lintasan-H & 5 & 67,44 & 336 & 0,1705 & 0,0146 \\
\hline
\end{tabular}

Gambar 8 menunjukkan model tahanan jenis hasil inversi dari data MT di daerah Wapsalit. Tiga lintasan di bagian utara (Lintasan A, B dan C) mempunyai pola tahanan jenis bawah permukaan yang mirip dimana zona konduktif berada di bagian barat daya hingga tengah lintasan dengan ketebalan mencapai $1.000 \mathrm{~m}$ di bagian tengah. Zona resistif dengan nilai tahanan jenis lebih dari 750 Ohm.m terletak di barat daya lintasan dari kedalaman $2.000 \mathrm{~m}$

Zona konduktif dengan nilai tahanan jenis kurang dari 40 Ohm.m juga muncul di lintasan $D$ dan $E$ dengan kedalaman 500 hingga $1.000 \mathrm{~m}$ dari permukaan dan memanjang sepanjang lintasan. Zona resistif muncul di tengah lintasan $D$ di bagian bawah, dan di bagian barat daya lintasan E. Struktur tahanan jenis di lintasan yang lainnya mempunyai sebaran yang mirip, dimana zona konduktif berada di dekat permukaan dengan ketebalan yang bervariasi. Sedangkan zona resistif terletak di bagian bawah di bagian barat daya dan timur laut dari lintasan $F$ dan $G$, serta di bagian tengah lintasan $\mathrm{H}$.
Gambar 9 menunjukkan distribusi lateral tahanan jenis bawah permukaan hasil inversi dari kedalaman 500 hingga 3.500 $\mathrm{m}$. Zona konduktif mendominasi di hampir semua bagian di dekat permukaan hingga kedalaman $1.000 \mathrm{~m}$. Pada kedalaman $1.250 \mathrm{~m}$, zona konduktif masih mendominasi, namun di bagian barat laut, timur laut, selatan dan sekitar manifestasi permukaan menjadi lebih resistif. Zona konduktif tersebut menjadi zona resistif yang ditunjukkan oleh warna hijau pada kedalaman $1.500 \mathrm{~m}$.

Di lapisan bawah, nilai tahanan jenis bertambah di hampir seluruh area. Warna biru yang menunjukkan zona resistif muncul di bagian barat laut dan timur laut. Di daerah manifestasi permukaan, nilai tahanan jenis sedang muncul di lapisan atas dan menjadi semakin resistif seiring dengan bertambahnya kedalaman. Di bagian utara dan timur, zona konduktif masih muncul hingga bagian yang lebih dalam. Di bagian selatan, zona konduktif masih muncul hingga kedalaman $2.000 \mathrm{~m}$, namun menjadi lebih resistif di kedalaman juga. 


\section{MAKALAH ILMIAH}

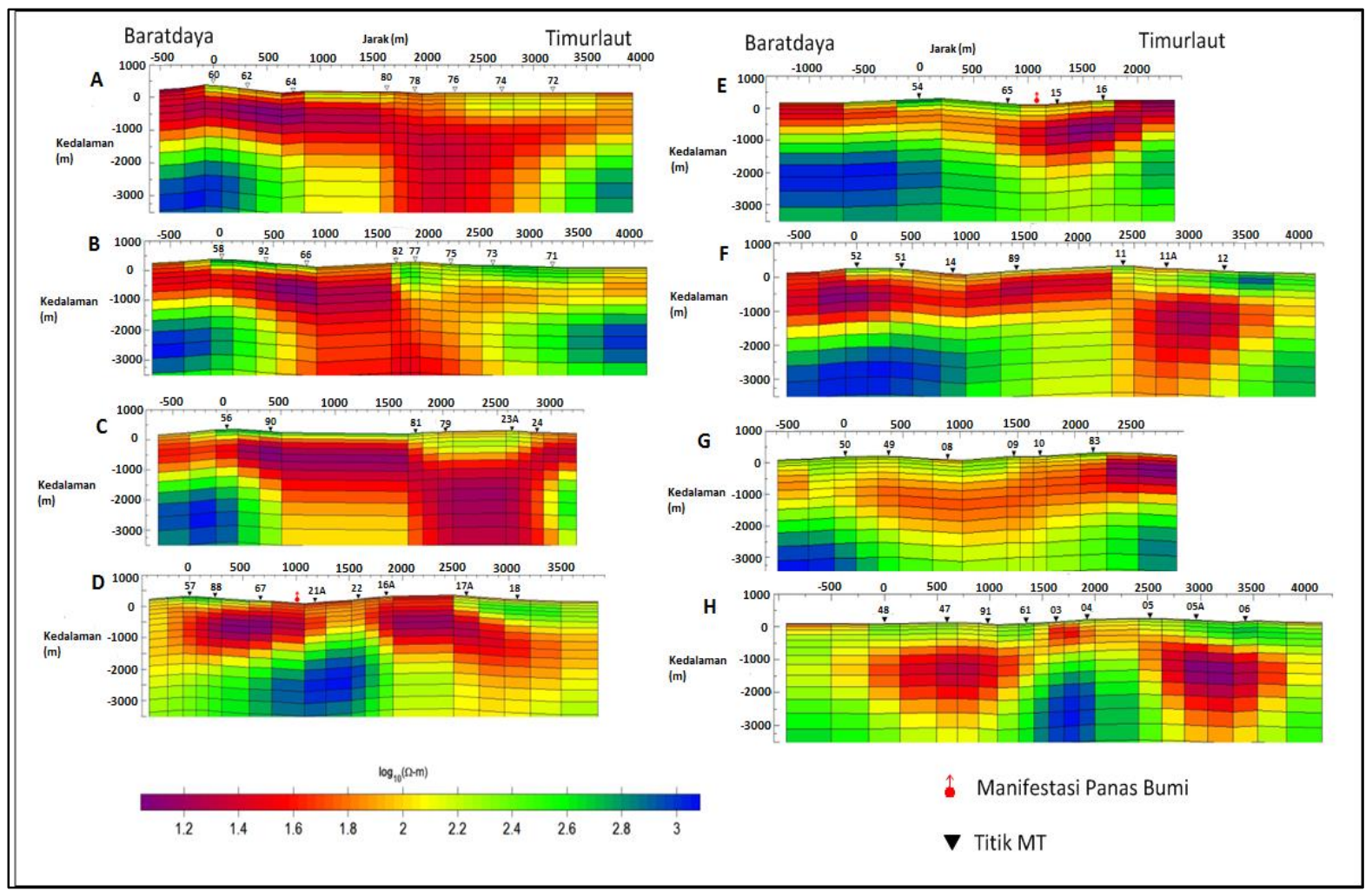

Gambar 6. Model tahanan jenis hasil inversi 2-D di daerah panas bumi

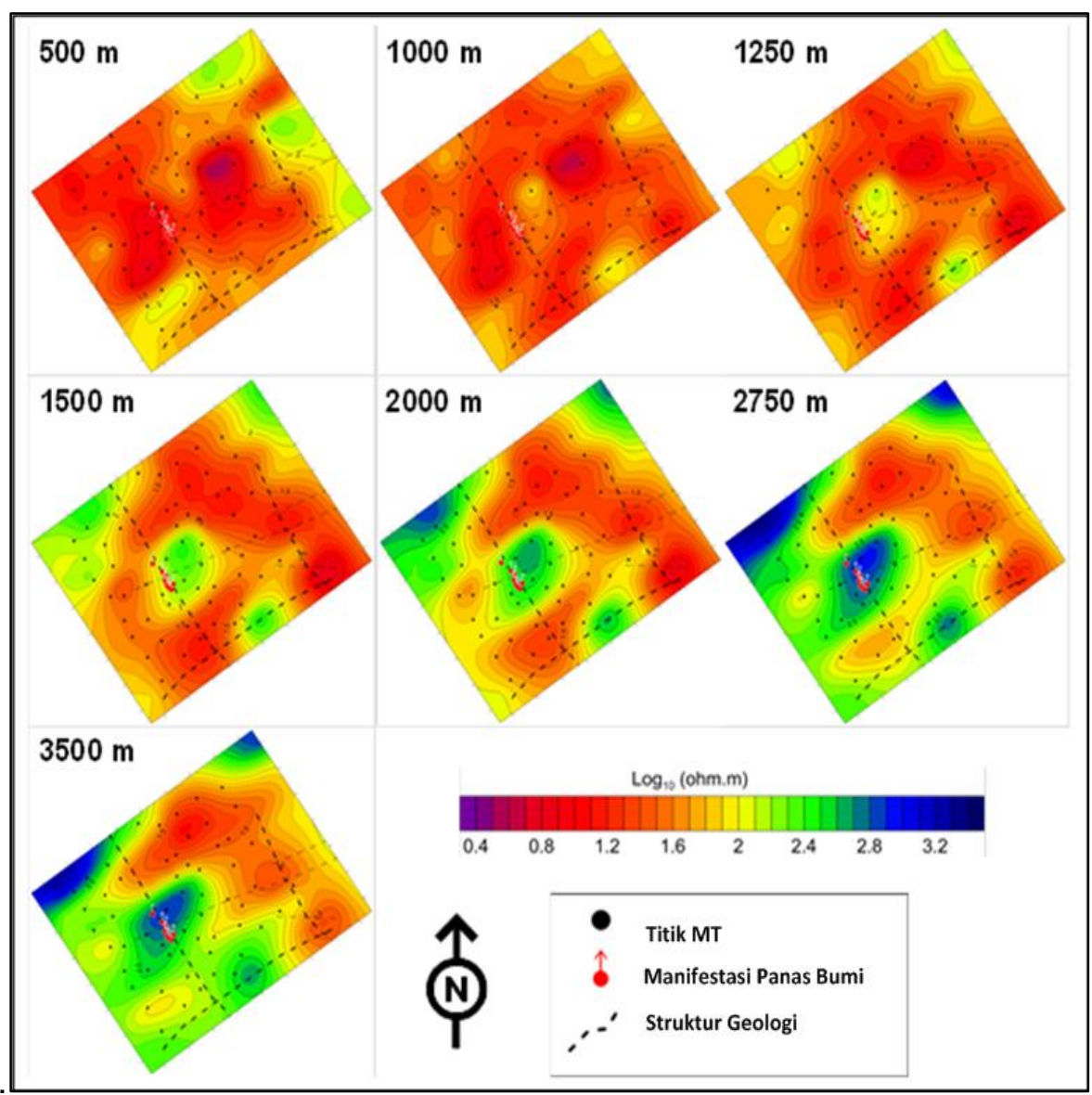

Gambar 7. Distribusi tahanan jenis lateral per kedalaman di daerah panas bumi Wapsalit 


\section{MAKALAH ILMIAH}

\section{DISKUSI}

Berdasarkan hasil survei MT ini diduga bahwa zona prospek daerah Wapsalit terletak di sekitar manifestasi permukaan. Manifestasi permukaan yang berupa mataair panas, tanah panas, fumarol, dan batuan alterasi dikontrol oleh perpotongan dari sesar Waekedang (barat laut tenggara) dan komplek sesar Metar (barat daya - timur laut).

Berdasarkan sebaran tahanan jenis, zona konduktif berada di bagian tengah area (sekitar manifestasi panas bumi) yang tersebar mulai dari permukaan. Pada kedalaman 500 meter zona konduktif ini masih tersebar dominan terutama dibagian tengah area dan dibagian baratlaut. Pada bagian tengahnya ini diduga berasosiasi dengan batuan metamorf yang teralterasi dan bersifat impermeabel (Hadi \& Sulaeman, 2010). Lapisan konduktif $(<40$ Ohm.m) ini dinterpretasikan sebagai batuan penudung dari sistem panas bumi Wapsalit dengan ketebalan 1.000 hingga $1.250 \mathrm{~m}$ (Gambar 10).

Pada kedalaman $1.500 \mathrm{~m}$, sebaran nilai tahanan jenis dibagian tengah ini mengalami peningkatan (lebih resistif dibandingkan lapisan diatasnya). Zona ini memiliki rentang nilai tahanan jenis antara 50 hingga 300 Ohm.m. Zona ini diinterpretasikan sebagai zona reservoir dari sistem panas bumi. Umumnya nilai tahanan jenis di reservoir lebih tinggi dibandingkan dengan nilai tahanan jenis batuan penudung. Kontras tahanan jenis yang muncul pada bagian barat dari zona ini pada kedalaman $1.500 \mathrm{~m}$ diperkirakan berasosiasi dengan sesar Waekedang. Kontras tahanan jenis juga muncul dibagian utara, timur dan selatan dari zona tersebut. Keempat kontras ini membentuk batasan bagi zona prospek panas bumi di daerah Wapsalit.

Nilai tahanan jenis tinggi lebih dari 1.000 Ohm.m muncul di lapisan bawah dari zona prospek dengan bentuk menyerupai kubah. Nilai tahanan jenis tinggi ini berhubungan dengan anomali gaya berat tinggi (Rezky dan Zarkasyi, 2010) dan diperkirakan sebagai intrusi batuan vulkanik muda yang berlaku sebagai sumber panas dari sistem panas bumi Wapsalit (lihat profil penampang pada Gambar 10). Pada kedalaman 2750 m dibagian zona prospeknya semakin resistif yang diduga merupakan tubuh dari batuan intrusif batuan vulkanik muda.

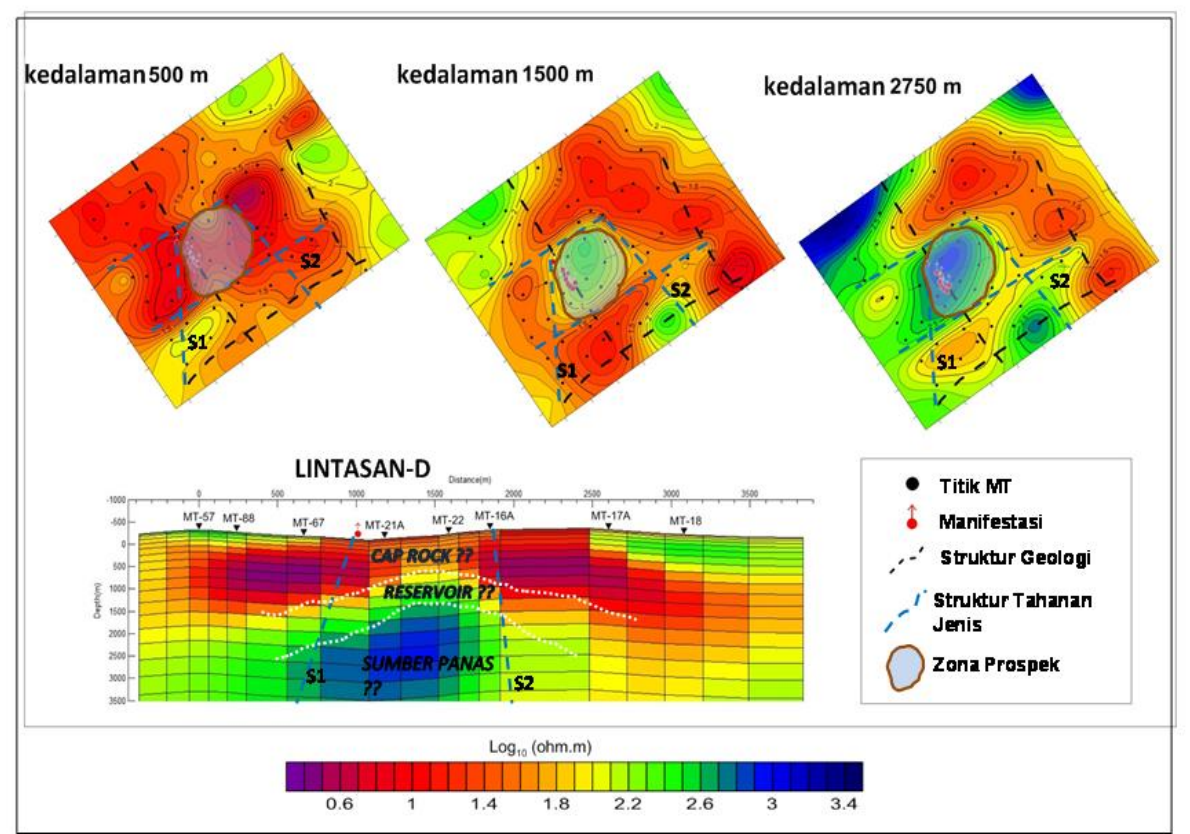

Gambar 8. Interpretasi struktur tahanan jenis dari data MT di daerah panas bumi Wapsalit. 


\section{KESIMPULAN}

Distribusi nilai tahanan jenis dapat digunakan untuk mendelineasi zona prospek panas bumi. Zona prospek panas bumi Wapsalit terletak di sekitar manifestasi permukaan dan memanjang ke bagian timur. Batuan metamorf teralterasi tersingkap di permukaan dan ditunjukkan sebagai lapisan konduktif hingga kedalaman 1.000 sampai $1.250 \mathrm{~m}$. Lapisan ini diinterpretasikan sebagai batuan penudung dari sistem panas bumi Wapsalit.

Zona reservoir dengan perkiraan temperatur sebesar $240^{\circ} \mathrm{C}$ terletak di bawah batuan penudung dan ditunjukkan sebagai lapisan tahanan jenis menengah dengan rentang nilai $50-300$ Ohm.m. Puncak dari zona reservoir ini diperkirakan berada pada kedalaman $1.500 \mathrm{~m}$. Zona resistif di lapisan paling bawah diperkirakan sebagai bagian dari batuan panas yang yang berperan sebagai sumber panas yang berada jauh pada kedalaman di bawah zona prospek sistem panas bumi Wapsalit.

\section{UCAPAN TERIMA KASIH}

Penulis mengucapkan terima kasih kepada Pusat Sumber Daya Mineral Batubara dan Panas Bumi yang telah memberikan izin dalam mengolah data MT ini. Penulis pertama juga mengucapkan terima kasih kepada Prof. Hideki Mizunaga dari Kyushu University atas bimbingannya mengenai topik ini.

\section{DAFTAR ACUAN}

Buonasorte, G., Caranova, R., Fiordelisi, A., \& Ungarelli, C. (2013). MT as a tool for Geothermal exploration : a case study from Southern Tuscany. European Geothermal Congress. Pisa: EGC.

Chave, A. D., \& Jones, A. G. (2012). The Magnetotelluric Method Theory and Practice. Cambridge: Cambridge University Press.
Chave, A. D., \& Weidelt, P. (2012). The Theoritical Basis for Electromagnetic Induction. In A. D. Chave, \& A. G. Jones, The Magnetotelluric Method (pp. 19-44). Cambridge: Cambridge University Press.

Goldstein, B., Hill, A., Long, A., Budd, A., Holgate, F., \& Malavazos, M. (2009). Hot Rock Geothermal Energy Plays in Australia. Thirty-Fourth Workshop on Geothermal Reservoir Engineering. Standford University, California.

Grandis, H. (2009). Pengantar Pemodelan Inversi Geofisika. Jakarta: HAGI.

Hadi, M. N., \& Sulaeman, B. (2010). Surface Manifestation in Wapsalit Geothermal Area, Buru Island, Indonesia. Proceeding World Geothermal Congress 2010. Bali.

Kholid, M., Widodo, S., \& Rezky, Y. (2015). 2D Inversion of Magnetotelluric Data from Wapsalit Geothermal Field, Indonesia. World Geothermal Congress. Melbourne.

King, R., \& Miller , M. (2010). Multiuse "Triple Play" Hot Sedimentary Aquifer (HSA) Potential of Victoria, Australia. World Geothermal Congress . Bali.

Lee, S. K., Kim, H. J., Song, Y., \& Lee, C. K. (2009). MT2DInvMatlab--A program in MATLAB and FORTRAN for two-dimensional magnetotelluric inversion. Computer \& Geosciences 35, 1722-1734.

Niasari, S. W., Munoz, G., Kholid, M., Suhanto, E., \& Ritter , O. (2015). 3D Inversion of Magnetotelluric Data from the Sipoholon Geothermal Field, Sumatera, Indonesia. World Geothermal Congress. Melbourne.

Rezky, Y., \& Zarkasyi, A. (2010). Indication of Intrusive Body in Wapsalit Geothermal Area, Buru Island, Indonesia. World Geothermal Congress. Bali. 


\section{MAKALAH ILMIAH}

Uchida, T., Takakura, S., Ueda, T., Adachi, M., Ozeki, H., Kamada, K., et al. (2011). 3D Magnetotelluric Survey at The Yanaizu-Nishiyama Geothermal Field, Northern Japan. Proceedings of the 9th Asian Geothermal Symposium. Ibusuki.
Zarkasyi, A., \& Takodama, I. (2016).

Survei Magnetotellurik dan Time Domain Elektromagnetik Daerah Panas Bumi Wapsalit, Kabupaten Buru, Provinsi Maluku. Bandung: Pusat Sumber Daya Mineral Batubara dan Panas Bumi.

$\begin{array}{ll}\text { Diterima } & : 10 \text { September } 2018 \\ \text { Direvisi } & : 27 \text { September } 2018 \\ \text { Disetujui } & : 29 \text { November } 2018\end{array}$

